\title{
Characterization of Growth and Inulinase Production by Bifidobacterium spp. on Fructooligosaccharides
}

\author{
R.C. McKellar, H.W. Modler and J. Mullin \\ Centre for Food and Animal Research, Research Branch, Agriculture Canada, Ottawa K1A OC6, Canada
}

(Received for publication, August 24, 1993)

\begin{abstract}
A total of 19 species of Bifidobacterium were screened for the ability to grow with fructooligosaccharides (FOS) as the carbohydrate source. Several strains of animal origin (B. thermophilum, B. minimum, and $B$. cuniculi) grew significantly better than strains from human source on inulin (degree of polymerization $(D P) \geq 15$ ). These strains grew equally well on inulin from several sources, but were unable to metabolize levan, a polymer of $\beta(2-6)$-D-fructose. Best growth was obtained on FOS preparations containing a significant proportion of low-molecular-weight (DP $\leq 5)$ carbohydrates. Strains which grew best on inulin required the presence of this FOS for maximal induction of the exo-inulinase. These results suggest that animal strains of bifidobacteria may be used in conjunction with short-chain FOS as a supplement to animal feed.
\end{abstract}

Key words: bifidobacteria; fructooligosaccharides (FOS); inulinase

The widespread use of antibiotics in animal feed to reduce disease and improve animal performance, and thus profitability, has come under criticism for increasing the antibiotic resistance of many bacteria, including some pathogens. Organisms which cause respiratory and cutaneous infections (Streptococcus pneumoniae, Streptococcus pyogenes and staphylococci) as well as diarrhea, urinary infection and sepsis (Enterobacteriaceae, Pseudomonas families) are now resistant to many of the older antibiotics (13). This concern, with antimicrobial agent becoming less effective, has prompted many investigations into mechanisms to replace antibiotics with probiotic agents in animal feed rations (7).

The administration of probiotic agents in animal feeds has met with limited success and produced highly variable results (16). Most of the preparations contain lactobacillus preparations, and more recently bifidobacteria species have been added to many of the probiotic preparations. Lactobacilli tend to occupy the more proximal area of the gastrointestinal tract (GI) $(16,18)$, while bifidobacteria inhabit principally the large intestine or cecal areas $(11)$.

Bifidobacteria inhibit the growth of many undesirable organisms in the lower GI (5) through the production of lactic and acetic acid (15). By controlling intes- 
tinal $\mathrm{pH}$ it is possible to restrict the growth of pathogens and putrefactive bacteria and in turn reduce the production of phenols, ammonia, steroid metabolites, bacterial toxins as well as vasoconstricting amines (5). To be of benefit to the host, bifidobacteria must receive sources of carbohydrate, termed bifidogenic factors (10), for metabolism in the lower bowel/ceca area. Ideally such compounds should be not be metabolized by the host and arrive intact at the distal end of the small intestine and colon/cecal areas of the GI tract (9).

There are a number of compounds which can survive gastric digestion and be delivered to the lower GI for metabolism by bifidobacteria (10). To date, the poymers of $\mathrm{D}$-fructose, joined by $\beta(1-2)$ linkage, have received the most attention. The short-chained polymers, termed neosugars, consist of glucose $(\mathrm{G})$-fructose $(\mathrm{F})$ linkages to form $\mathrm{GF}_{2}, \mathrm{GF}_{3}$ and $\mathrm{GF}_{4}$ compounds $(5,6)$. These compounds can be produced by enzymatic means (6) while the longer-chained fructan polymers are obtained from natural sources such as chicory, Jerusalem artichoke tubers or dahlia (10).

The feeding of bifidobacteria and fructooligosaccharides (FOS) to young animals has been suggested as a method for improving weight gain and feed efficiency, as well as providing protection from colonization by Salmonella spp.; however, there are limited data describing the effects or benefits of adding FOS to animal feed rations. Bailey et al. (3) observed that when an undefined FOS was fed to chickens, there was a 1 to $2 \log$ reduction of Salmonella typhimurium in challenged chicks when the diet was supplemented with $0.75 \%$ FOS. When the chicks were given a combination of FOS $(0.75 \%)$ and an undefined competitive exclusion culture, $81 \%$ of the chicks were Salmonella free. Chickens treated with FOS had a fourfold reduction in the level of Salmonella present in the cecum. Bailey et al. (3) concluded that chickens fed FOS may have an altered intestinal gut flora and this could increase their resistance to Salmonella colonization. Others (9) observed that $2 \%$ FOS in poultry rations reduced cecum $\mathrm{pH}$ by about $0.4 \mathrm{pH}$ units over control treatments but the effect on Salmonella colonization was not determined.

There are other studies which indicate that feeding probiotic bacteria alone may be sufficient to competitively exclude pathogens. Schleifer (16) reported some success in poultry experiments, while both Beeman (4) and Wren (22) demonstrated some utility for lactobacilli preparations in calf diets. It is well known that lactobacilli tend to occupy the more proximal areas of the digestive tract of poultry, through attachment to the squamous epithelial tissue (19). Bifidobacteria do not appear to live in close association with the epithelium tissue, and are generally found in the most distal area of the digestive tract and reside in the gut lumen (20).

Metabolism of FOS by bifidobacteria is made possible by the splitting off of fructose moieties by a cell-bound inulinase or 2,1- $\beta$-D-fructan-fructanohydrolases (EC 3.2.1.7) (8). This enzyme has been previously characterized and shown to be constitutive in human, and inducible in animal strains. The inulinase from all strains studied was repressed by monosaccharides $(8)$. There have been few reports of characterization of inulinases from bifidobacteria (12) and other bacteria $(1,2,21)$. 
Some intestinal pathogens can metabolize short-chain FOS; thus in order to maximize the efficient use of FOS, it is necessary to determine which Bifidobacterium spp. metabolize FOS, and what is the most efficient chain length and source of this polysaccharide. The purpose of the present study is to (1) select strains of bifidobacteria which can metabolize long-chain FOS such as inulin and (2) characterize the influence of environmental factors on growth and induction of inulinase.

\section{MATERIALS AND METHODS}

Strains and culture conditions. Strains of bifidobacteria used in this study are described in Table 1. Cells were routinely cultured in $10 \mathrm{ml}$ of TPY broth $(8)$ anaerobically under $\mathrm{CO}_{2} / \mathrm{H}_{2}$ (Scott Anapak, Scott Laboratories, Fiskeville, RI) at $37^{\circ} \mathrm{C}$, and transferred every $72 \mathrm{hr}$.

Carbohydrate source. The following FOS were used: raffinose, inulin from dahlia tubers, inulin from chicory root, and inulin from Jerusalem artichoke tubers (all from Sigma Chemical Company, St. Louis, MO); purified neosugars (P) from Meiji Seika Kaisha; Fibruline (see Table 2 for composition) from Cosucra, Momale, Belgium; and levan (a polymer of $\beta(2-6)$-D-fructose) kindly provided by Dr. P.J. Wan, SRRC/USDA, New Orleans, LA. Inulin from dahlia tubers (Sigma) was used at $0.5 \%(\mathrm{w} / \mathrm{v})$ as the carbohydrate source unless specified otherwise.

HPLC procedures. The oligo- and polysaccharides were separated on a $4 \times$ 250 mm Dionex Carbopac PA-100 column fitted with a Carbopac PA-100 guard column. Samples were applied from a manual Rheodyne \#7161 injector with a $200 \mu \mathrm{l}$ sample loop. The eluting gradient was provided from a Waters 600 pump and control system, the flow rate was $1 \mathrm{ml} / \mathrm{min}$ and the gradient was as follows: with constant $100 \mathrm{~mm} \mathrm{NaOH}$ throughout the program, the initial concentration of $\mathrm{Na}$ Acetate was $100 \mathrm{~mm}$ increasing to $550 \mathrm{~mm}$ over $80 \mathrm{~min}$, then returning to $100 \mathrm{~mm}$ over $5 \mathrm{~min}$ to equilibrate for $5 \mathrm{~min}$ before injecting the next sample. The detector was a Waters 464 Pulsed Electrochemical Detector provided with a post column addition pump to add $0.5 \mathrm{M} \mathrm{NaOH}, 1.0 \mathrm{ml} / \mathrm{min}$ to the column effluent immediately before entering the detector cell. The detector pulse potentials and durations were as follows: $\mathrm{E}_{1}=-100 \mathrm{mv},(216 \mathrm{~ms}) ; \mathrm{E}_{2}=+550 \mathrm{mv},(216 \mathrm{~ms}) ; \mathrm{E}_{3}=-750 \mathrm{mv}$, (299 ms). All data were collected and processed using the Waters 991 Powerline system.

Cell fractionation. Cells were centrifuged at $6000 \times \mathrm{g}$ for $10 \mathrm{~min}$, washed in $50 \mathrm{~mm}$ TES buffer (Sigma) pH 7.5, and resuspended in $5 \mathrm{ml}$ of TES. Cells were broken by sonication for $5 \mathrm{~min}$ at maximum power on low setting using a Sonic 2000 (Braun, Bethlehem, PA) fitted with a needle probe. Unbroken cells were removed by centrifugation at $480 \times g$ for 5 min.

Growth experiments. Cells from a TPY stock culture were inoculated (1\% v/v) in fresh TPY and incubated anaerobically at $37^{\circ} \mathrm{C}$ for $48 \mathrm{hr}$, then inoculated $(1 \%)$ into $10 \mathrm{ml}$ of TPY containing $0.5 \%(\mathrm{w} / \mathrm{v})$ of carbohydrate. After a further $48 \mathrm{hr}$ of anaerobic incubation at $37^{\circ} \mathrm{C}$, growth was determined by measuring the increase in absorbance at $600 \mathrm{~nm}$ of an appropriate dilution with a Spectronic 2000 (Bausch 
Table 1. Bifidobacterium spp. used in the present study

\begin{tabular}{|c|c|c|}
\hline $\begin{array}{c}\text { CFAR } \\
\#\end{array}$ & Strain & Source \\
\hline 61 & Bifidobacterium adolescentis & ATCC 15703 \\
\hline 63 & Bifidobacterium longum & Commercial \\
\hline 66 & Bifidobacterium infantis & ATCC 15697 \\
\hline 67 & Bifidobacterium breve & ATCC 15700 \\
\hline 68 & Bifidobacterium longum & ATCC 15707 \\
\hline 69 & Bifidobacterium longum & ATCC 15708 \\
\hline 70 & Bifidobacterium thermophilium & ATCC 25525 \\
\hline 115 & Bifidobacterium bifidum & Commercial \\
\hline 116 & Bifidobacterium bifidum & Commercial \\
\hline 117 & Bifidobacterium bifidum & Commercial \\
\hline 118 & Bifidobacterium breve/longum & Commercial \\
\hline 119 & Bifidobacterium species & Commercial \\
\hline 120 & Bifidobacterium species & Commercial \\
\hline 121 & Bifidobacterium species & Food isolate \\
\hline 122 & Bifidobacterium longum & Commercial \\
\hline 123 & Bifidobacterium longum & Commercial \\
\hline 124 & Bifidobacterium bifidum & ATCC 29521 \\
\hline 169 & Bifidobacterium bifidum & Commercial \\
\hline 170 & Bifidobacterium bifidum & Commercial \\
\hline 171 & Bifidobacterium bifidum & Commercial \\
\hline 172 & Bifidobacterium thermophilum & Commercial \\
\hline 319 & Bifidobacterium gallinarum & St. Hyacinthe \\
\hline 320 & Bifidobacterium pullorum & St. Hyacinthe \\
\hline 321 & Bifidobacterium globosum & St. Hyacinthe \\
\hline 322 & Bifidobacterium animalis & St. Hyacinthe \\
\hline 323 & Bifidobacterium thermophilum & St. Hyacinthe \\
\hline 324 & Bifidobacterium cuniculi & St. Hyacinthe \\
\hline 325 & Bifidobacterium choerinum & St. Hyacinthe \\
\hline 326 & Bifidobacterium minimum & St. Hyacinthe \\
\hline 327 & Bifidobacterium boum & St. Hyacinthe \\
\hline 328 & Bifidobacterium pseudolongum & St. Hyacinthe \\
\hline 329 & Bifidobacterium suis & St. Hyacinthe \\
\hline 330 & Bifidobacterium magnum & St. Hyacinthe \\
\hline 331 & Bifidobacterium subtilis & St. Hyacinthe \\
\hline 332 & Bifidobacterium bifidum & $\mathrm{H} \& \mathrm{~W} \# 781$ \\
\hline 333 & Bifidobacterium infantis & $\mathrm{H} \& \mathrm{~W} \# 782$ \\
\hline 334 & Bifidobacterium breve & $\mathrm{H} \& \mathrm{~W} \$ 783$ \\
\hline 335 & Bifidobacterium adolescentis & $\mathrm{H} \& \mathrm{~W} \# 784$ \\
\hline 336 & Bifidobacterium longum & H \& W $\# 785$ \\
\hline 337 & Bifidobacterium cuniculi & ATCC 27916 \\
\hline 338 & Bifidobacterium ruminantium & ATCC 49390 \\
\hline 339 & Bifidobacterium merycicum & ATCC 49391 \\
\hline 347 & Bifidobacterium thermophilum & ATCC 25866 \\
\hline 348 & Bifidobacterium thermophilum & ATCC 25867 \\
\hline
\end{tabular}


Table 2. Composition of commercial inulin preparations

\begin{tabular}{|c|c|c|c|c|}
\hline $\begin{array}{c}\text { Degree of } \\
\text { polymerization }\end{array}$ & Fibruline ${ }^{a}$ & $\begin{array}{c}\text { Inulin from } \\
\text { dahlia }\end{array}$ & $\underset{\mathrm{JA}}{\text { Inulin from }}$ & $\begin{array}{l}\text { Inulin from } \\
\text { chicory }\end{array}$ \\
\hline & \multicolumn{4}{|c|}{ 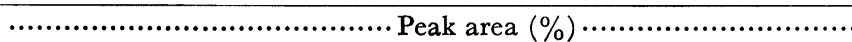 } \\
\hline $1+2$ & 7.8 & $<0.1$ & $<0.1$ & $<0.1$ \\
\hline 3 & 5.1 & $<0.1$ & $<0.1$ & $<0.1$ \\
\hline 4 & 4.6 & $<0.1$ & $<0.1$ & $<0.1$ \\
\hline 5 & 4.0 & $<0.1$ & $<0.1$ & $<0.1$ \\
\hline 6 & 4.2 & $<0.1$ & $<0.1$ & $<0.1$ \\
\hline 7 & 4.1 & $<0.1$ & $<0.1$ & $<0.1$ \\
\hline 8 & 4.0 & $<0.1$ & $<0.1$ & $<0.1$ \\
\hline 9 & 4.0 & 0.1 & $<0.1$ & $<0.1$ \\
\hline 10 & 3.9 & 0.3 & 0.1 & 0.2 \\
\hline 11 & 3.7 & 0.6 & 0.4 & 0.4 \\
\hline 12 & 3.3 & 1.1 & 0.8 & 0.7 \\
\hline 13 & 3.1 & 1.7 & 1.3 & 1.3 \\
\hline 14 & 2.9 & 2.4 & 1.8 & 1.9 \\
\hline 15 & 2.7 & 3.0 & 2.3 & 2.5 \\
\hline 16 & 2.6 & 3.5 & 2.6 & 2.9 \\
\hline 17 & 2.6 & 4.5 & 2.8 & 3.7 \\
\hline 18 & 2.4 & 4.8 & 3.0 & 4.0 \\
\hline 19 & 2.3 & 4.9 & 3.0 & 4.1 \\
\hline 20 & 2.2 & 4.9 & 3.0 & 4.2 \\
\hline 21 & 2.1 & 4.9 & 3.0 & 4.2 \\
\hline 22 & 1.9 & 4.7 & 3.0 & 4.2 \\
\hline 23 & 1.8 & 4.6 & 3.0 & 4.1 \\
\hline 24 & 1.7 & 4.2 & 3.0 & 4.0 \\
\hline 25 & 1.5 & 3.6 & 3.0 & 3.7 \\
\hline $26-30$ & 5.8 & 15.1 & 16.1 & 15.6 \\
\hline $31-35$ & 4.2 & 13.5 & 16.3 & 13.1 \\
\hline $36-40$ & 2.6 & 8.0 & 12.6 & 9.2 \\
\hline Total & 91.1 & 90.4 & 81.1 & 84.0 \\
\hline$<15$ & 39.67 & & & \\
\hline
\end{tabular}

a Produced from chicory by Cosucra (Momale, Belgium).

and Lomb, Rochester, NY). When the influence of $\mathrm{pH}$, temperature and atmosphere were being determined, the carbohydrate was $0.5 \%(\mathrm{w} / \mathrm{v})$ inulin from dahlia tubers. When the effect of $\mathrm{pH}$ was being determined, $\mathrm{pH}$ of TPY was adjusted to 6.0-9.0 using $\mathrm{HCl}$ prior to sterilization. When the effect of atmosphere was being considered, cultures were incubated in the presence and absence of cysteine hydrochloride $(0.05 \% \mathrm{w} / \mathrm{v})$, either aerobically, anaerobically, or in a $\mathrm{CO}_{2}$ chamber (Napco Model 6200, Napco Scientific Company, Tualatin, OR) under ambient air $+5 \%$ (v/v) $\mathrm{CO}_{2}$.

Inulinase assay. Inulinase activity was determined as described by McKellar and Modler ( 8$)$ using neosugar $(0.55 \% \mathrm{w} / \mathrm{v})$ as the substrate. Activity was expressed as $\mu$ moles fructose or glucose released per minute per milligram protein.

Protein determination. Protein was determined by the method of Lowry et al. as modified by Peterson (14). 


\section{RESULTS AND DISCUSSION}

\section{Metabolic Studies}

A total of 19 species of Bifidobasterium (43 strains total) (Table 1) were screened for ability to grow on various carbohydrate sources. Average growth for all strains was significantly $(p<0.05)$ better on glucose and sucrose as compared to the other carbon sources (Table 3 ). Inulin was the poorest carbon source tested. There were no significant differences between strains with respect to ability to grow on glucose $(p=0.1508)$ or sucrose $(p=0.2904)$; however, some strains grew significantly $(p \leq 0.05)$ better on fructose, neosugar and inulin (Table 3$)$.

These results agree with previous studies which showed that inulin was a poor carbon source for Bifidobacterium spp. (8). In contrast, Allais et al. (1) found that thermophilic bacilli grew equally well on all carbon sources including inulin.

All strains tested grew on neosugar as evidenced by increases in absorbance over control lacking carbohydrate of 0.256 to 2.13 (Table 4). The differences between strains were slight; however, the best growth was with $B$. minimum, B. cuniculi and $B$. thermophilum. The latter genus grew significantly better than all other strains (Table 4). With inulin as the carbohydrate source, 10 strains grew poorer than the control. The same three genera produced the best growth on inulin, with $B$. minimum giving the highest growth yield. Strains which grew best on neosugar also grew well on inulin. Simple linear regression gave an $\mathrm{r}^{2}$ of .52 for the relationship between these two carbohydrates (Fig. 1).

Several strains which gave the greatest yield on inulin were selected for further study. These included the 4 strains of $B$. thermophilum (CFAR 70, 323, 347, 348), $B$. minimum, and $B$. cuniculi. Table 5 shows the ability of these selected strains to grow on different sources of FOS. There was no significant difference between strains with respect to ability to grow on neosugar or levan (Table 5). With inulin from Jerusalem artichoke, dahlia, and chicory, two of the $B$. thermophilum spp. (CFAR 347 and 348) gave significantly lower growth yields compared to the other strains. When grown on Fibruline, CFAR 70 gave a significantly greater growth response than the other strains (Table 5).

Table 3. Effect of carbohydrate on average growth of Bifidobacterium spp. $(n=43)$

\begin{tabular}{lccc}
\hline Sugar & $\begin{array}{c}\text { Average growth } \\
\left(\mathrm{A}_{600}\right)\end{array}$ & $p$-Value & Pooled SE $^{3}$ \\
\hline Glucose & $1.704^{c}$ & 0.1508 & 0.0489 \\
Fructose & $1.208^{b}$ & 0.0076 & 0.0767 \\
Sucrose & $1.767^{c}$ & 0.2904 & 0.0643 \\
Neosugar & $1.258^{b}$ & 0.0000 & 0.0324 \\
Inulin & $0.0937 a$ & 0.0059 & 0.232 \\
\hline
\end{tabular}

1 Average growth yield for total of 43 strains.

2 Level of significance for between-species differences.

3 Pooled standard error for between-species differences.

$a, b, c$ Means not followed by the same letter are significantly $(p \leq 0.05)$ different. 
Table 4. Growth of various Bifidobacterium spp. on neosugar and inulin

\begin{tabular}{|c|c|c|c|}
\hline Strain & $n$ & $\begin{array}{c}\text { Neosugar } \\
\left(\mathrm{A}_{600}\right)\end{array}$ & $\begin{array}{l}\text { Inulin } \\
\left(\mathrm{A}_{600}\right)\end{array}$ \\
\hline B. boum & 1 & $0.256^{a}$ & $0.024 a b$ \\
\hline B. pseudolongum & 1 & $0.542^{a b}$ & $-0.051^{a}$ \\
\hline B. globosum & 1 & $0.659^{a b c}$ & $-0.092 a$ \\
\hline B. pullorum & 1 & $0.774 a b c d$ & $-0.068 a$ \\
\hline B. ruminantium & 1 & $0.889^{b c d e}$ & $-0.106^{a}$ \\
\hline B. choerinum & 1 & $0.900^{b c d e}$ & $-0.214^{a}$ \\
\hline B. animalis & 2 & $0.957 b c d e$ & $-0.016^{a}$ \\
\hline B. gallinarum & 1 & $1.09^{b c d e f}$ & $0.071 a b c d e f$ \\
\hline B. bifidum & 8 & $1.10^{e d e f g}$ & $-0.032^{a}$ \\
\hline B. breve & 2 & $1.13^{c d e f g h}$ & $-0.070^{a}$ \\
\hline B. longum & 6 & $1.18^{d e f g h i}$ & $0.002^{a}$ \\
\hline$B$. species & 4 & $1.21^{d e f g h i j}$ & $0.045^{a b c d e}$ \\
\hline B. suis & 1 & $1.22^{c d e f g h i j}$ & $-0.051 a$ \\
\hline B. breve/longum & 1 & $1.28^{\text {cdefghijk }}$ & $0.029 a b$ \\
\hline B. merycicum & 1 & $1.43^{e f g h i j k l}$ & $0.042 a b c d$ \\
\hline B. magnum & 1 & $1.47 e f g h i j k l$ & $-0.051^{a}$ \\
\hline B. adolescentis & 2 & $1.54^{f h i j k l}$ & $0.041 a b c$ \\
\hline B. infantis & 2 & $1.57 f h j k l$ & $0.300^{b d f g}$ \\
\hline B. minimum & 1 & $1.85^{\mathrm{klm}}$ & $0.670^{h}$ \\
\hline B. cuniculi & 1 & $2.05 \mathrm{~lm}$ & $0.578^{g h}$ \\
\hline B. thermophilum & 4 & $2.13^{m}$ & $0.390^{g h}$ \\
\hline Total & 43 & & \\
\hline
\end{tabular}

$a \sim m$ Values in the same column not followed by the same letter are significantly different $(p \leq 0.05)$.

Values are the means of two trials.

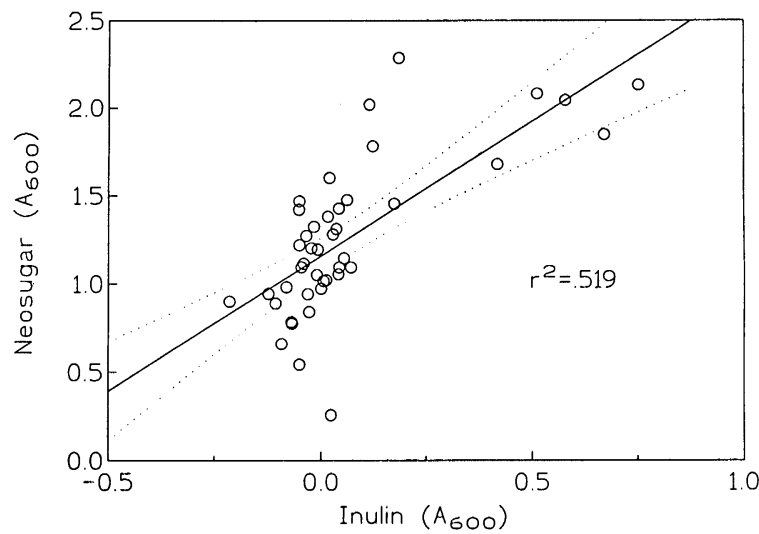

Fig. 1. Relationship between growth on neosugar and inulin for all Bifidobacterium spp. $(n=43)$. Values are the means of two trials. 
Table 5. Growth of selected Bifidobacterium spp. on various sources of fructooligosaccharides

\begin{tabular}{|c|c|c|c|c|c|c|}
\hline Species & Levan & JA & Dahlia & Chicory & Fibruline & Neosugar \\
\hline & & & & $\cdots \mathrm{A}_{600} \cdot$ & & \\
\hline CFAR 70 & $0.137 a$ & $0.760^{b}$ & $0.843^{b}$ & $0.94^{b}$ & $2.05^{c}$ & $2.22^{a}$ \\
\hline CFAR 323 & $0.137 a$ & $0.994^{b}$ & $0.852^{b}$ & $0.872^{b}$ & $1.78^{b}$ & $2.23^{a}$ \\
\hline CFAR 347 & $0.057 a$ & $0.279 a$ & $0.361 a$ & $0.357 a$ & $1.36^{a}$ & $2.13^{a}$ \\
\hline CFAR 348 & $0.081^{a}$ & $0.295^{a}$ & $0.377 a$ & $0.434 a$ & $1.41^{a}$ & $1.94 a$ \\
\hline B. minimum & $0.092^{a}$ & $0.747 b$ & $0.843^{b}$ & $0.875^{b}$ & $1.46^{a}$ & $1.11^{a}$ \\
\hline B. cuniculi & $0.203^{a}$ & $0.827 b$ & $0.959^{b}$ & $1.08^{b}$ & $1.92^{b c}$ & $2.29 a$ \\
\hline
\end{tabular}

JA, inulin from Jerusalem artichoke tubers; Dahlia, inulin from dahlia tubers; Chicory, inulin from chicory; Fibruline, fibruline; Neosugar, purified neosugars $(\mathrm{P})$.

$a, b, c$ Values in the same column not followed by the same letter are significantly different $(p \leq 0.05)$.

Values are the means of two trials.

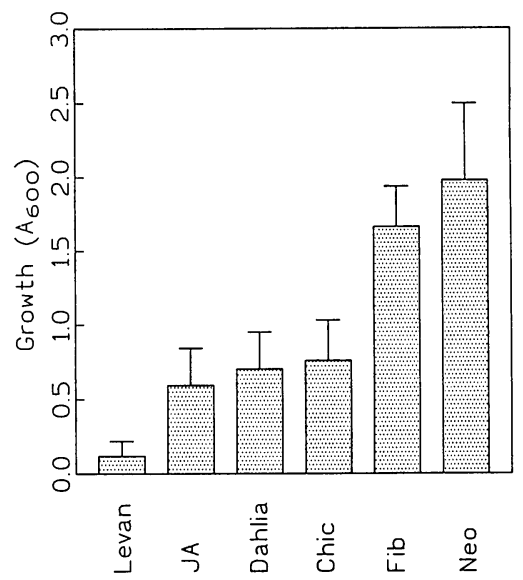

Fig. 2. Effect of source of fructooligosaccharide on growth of Bifidobacterium species. JA, Jerusalem artichoke flour; Dahlia, inulin from dahlia tubers; Chic, inulin from chicory; Fib, fibruline; Neo, neosugar. Data from strains CFAR 70, 323, 347, 348, $B$. minimum, and B. cuniculi were pooled. Bars represent standard deviation (means of two trials).

Neosugar was the best overall carbohydrate source, giving a significantly greater cell yield for all the strains combined (Fig. 2). Growth on levan was poor, and the source of inulin seemed not to be significant. Fibruline supported almost the same level of growth as neosugar. This is not surprising since $24.4 \%$ of the carbohydrate in fibruline has a DP of $\leq 5$ (Table 2).

Earlier work demonstrated that animal strains grew best on inulin $(8)$, and this was confirmed by the present study. The relationship between growth on neosugar and inulin suggests that the same enzyme is responsible for metabolism of these two substrates; absence of complete correlation may be related to the observed ability of some strains to grow on neosugar but not inulin, due likely to stearic hindrance $(8)$. 


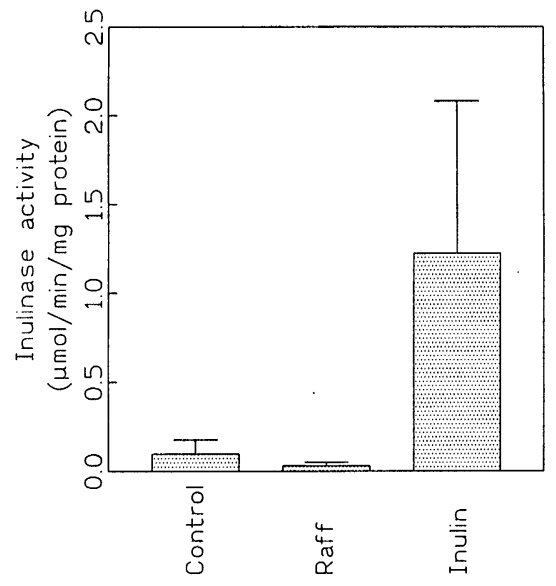

Fig. 3. Effect of fructooligosaccharide on induction of inulinase activity by Bifidobacterium species. Control, no fructooligosaccharide; Raff, raffinose; Inulin, inulin from dahlia tubers. Data from strains CFAR 70, 323, 347, 348, B. minimum, and B. cuniculi were pooled. Bars represent standard deviation (means of two replicates from two trials).

Table 6. Inulinase activity of selected species of Bifidobacterium after growth on various carbohydrates

\begin{tabular}{|c|c|c|c|}
\hline Species & Control & Raffinose & Inulin \\
\hline & \multicolumn{3}{|c|}{ 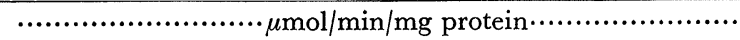 } \\
\hline CFAR 70 & $0.211^{c}$ & $0.063^{c}$ & $1.39 b c$ \\
\hline CFAR 323 & $0.040 a$ & $0.016^{a}$ & $0.680^{a}$ \\
\hline CFAR 347 & $0.081 a b$ & $0.025^{a}$ & $1.02 a b c$ \\
\hline CFAR 348 & $0.047 a$ & $0.020 a$ & $0.984 a b$ \\
\hline B. minimum & $0.062 a b$ & $0.021 a$ & $1.01 a b$ \\
\hline B. cuniculi & $0.140^{b c}$ & $0.046^{b}$ & $1.50^{c}$ \\
\hline
\end{tabular}

$a, b, c$ Values in the same column not followed by the same letter are significantly different $(p \leq 0.05)$.

Values are the means of two replicates of two trials.

Levan was not a good substrate for growth of animal strains of bifidobacteria. Muramatsu et al. (12) also showed that bifidobacteria from human origin failed to utilize levan. Fibruline, consisting of a large proportion of short-chain FOS, was the best inulin preparation, confirming previous observations that bifidobacteria preferred short-chain FOS to inulin $(8,12)$.

The ability of raffinose and inulin to induce inulinase production is shown in Fig. 3. Significant inulinase was only produced with inulin as carbohydrate source. When inulinase production by individual strains was compared, $B$. cuniculi gave higher activity than CFAR 323, CFAR 348 and B. minimum (Table 6). CFAR 70 gave greater activities than CFAR 323, and also produced higher levels of inulinase on raffinose and in the absence of carbohydrate (Table 6). 


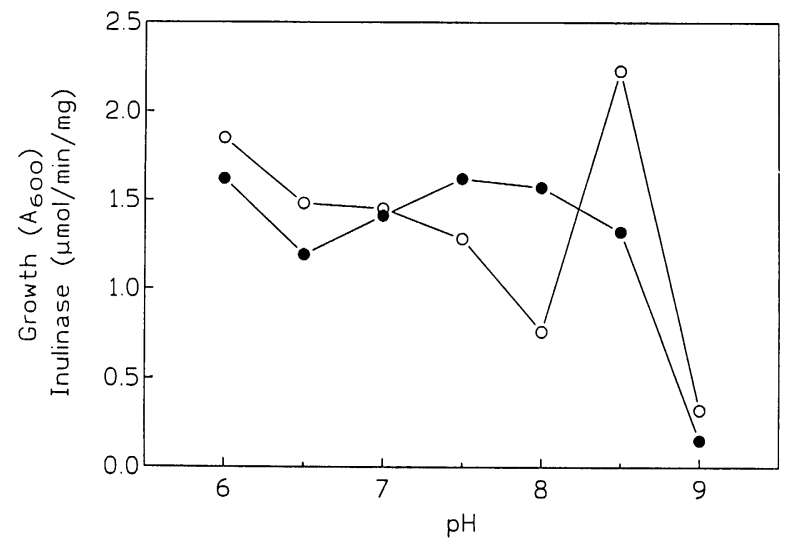

Fig. 4. Effect of $\mathrm{pH}$ on induction of inulinase activity (O) and growth (O) of strain CFAR 70. Values are the means of two replicates of two trials.

Table 7. Effect of atmosphere and cysteine $\mathrm{HCl}$ addition on growth and inulinase production by strain CFAR 70

\begin{tabular}{cccc}
\hline Conditions & Cysteine & $\begin{array}{c}\text { Activity } \\
(\mu \mathrm{mol} / \mathrm{min} / \mathrm{mg})\end{array}$ & $\begin{array}{c}\text { Growth } \\
\left(\mathrm{A}_{600}\right)\end{array}$ \\
\hline $\mathrm{O}_{2}$ & - & $1.07 a$ & $0.375^{a}$ \\
$\mathrm{O}_{2}$ & + & $1.19 a$ & $1.01^{b c}$ \\
$\mathrm{CO}_{2}$ & - & $1.22^{a}$ & $0.480^{a}$ \\
$\mathrm{CO}_{2}$ & + & $1.49 a$ & $1.30^{c}$ \\
$\mathrm{AnO}_{2}$ & - & $1.64 a$ & $0.798^{a b}$ \\
$\mathrm{AnO}_{2}$ & + & $2.40^{a}$ & $1.18^{b c}$ \\
\hline
\end{tabular}

$\mathrm{O}_{2}$, aerobic incubation; $\mathrm{CO}_{2}$, aerobic incubation with $5 \% \mathrm{CO}_{2} ; \mathrm{AnO}_{2}$, anaerobic incubation. $a, b, c$ Values in the same column not followed by the same letter are significantly different $(p \leq 0.05)$.

Values are the means of two replicates of two trials.

With all strains tested, inulin was required for maximum production of inulinase. Raffinose, previously shown to induce inulinase of Kluyveromyces fragilis (17), failed to induce significant levels of the enzyme. These results confirm and extend the previous observations $(8)$ that $B$. thermophilum CFAR 70 enzyme was induced by inulin while animal strains (which grew poorly on inulin) were constitutive, suggesting a possible link between inducibility and access of the physiological inducer (inulin) to the active site $(8)$. Allais et al. (1), in a study of inulinase produced by Flavobacterium spp., found that maximum levels of inulinase were found with inulin as the carbon source.

All further studies were conducted with CFAR 70. Inulinase production by CFAR 70 was affected by initial pH of the medium (Fig. 4). The activity at pH 8 and 9 was significantly $(p \leq 0.05)$ poorer than was found at 8.5 . Growth at $\mathrm{pH} 9.0$ was significantly $(p \leq 0.05)$ poorer than any of the other conditions. Significantly 


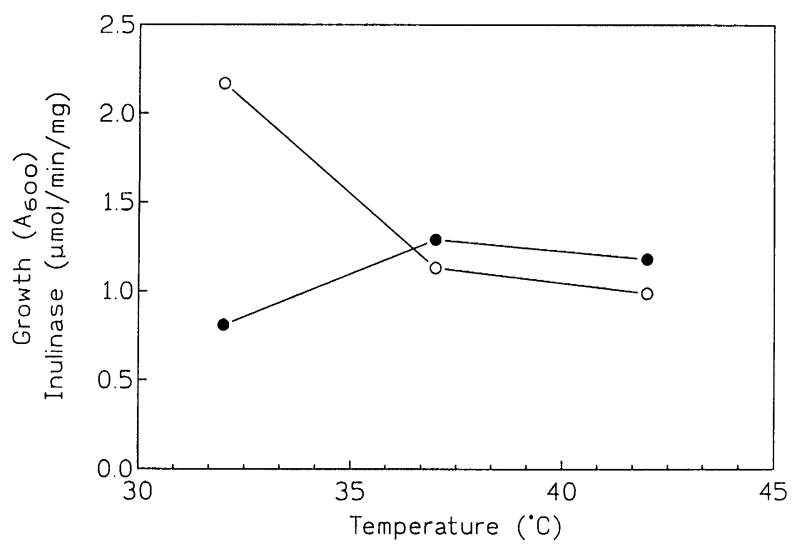

Fig. 5. Effect of temperature on induction of inulinase activity $(O)$ and growth of strain CFAR 70. Values are the means of two replicates of two trials.

( $p \leq 0.05$ ) less growth was also found at 6.5 compared to 6.0, 7.5, and 8.0 (Fig. 4).

The effect of atmosphere and cysteine on growth and inulinase production by CFAR 70 was examined (Table 7). Better inulinase production was noted with anaerobic conditions with cysteine; however, this activity was not significantly greater than the other conditions. The best growth was found anaerobically, and addition of cysteine increased growth under the other conditions (Table 7).

Temperature also had a significant effect on growth and inulinase production by CFAR 70 (Fig. 5). Growth was poorest at $32^{\circ} \mathrm{C}$; however, activity at this temperature was significantly greater than found at $43^{\circ} \mathrm{C}$.

\section{Animal Applications}

Marginal reductions in intestinal $\mathrm{pH}$, upon administration of FOS to animal diets suggests the lack of sufficient numbers of bifidobacteria to alter intestinal acidity, through the production of lactic and acetic acid. This situation may have evolved as the result of farming practices (isolation rearing of the young) or feed composition (lack of FOS components). Methods of improving the effectiveness of bifido-containing probiotics may include:

-Early administration of bifidobacteria to the host e.g. at birth;

-Incorporation of FOS into the feed components;

- Selection of animal strains of Bifidobacterium which can readily metabolize long-chained FOS components e.g. B. thermophilum, B. minimum and B. cuniculi;

In terms of animal application, it may be advantageous for probiotic preparations to contain both lactobacilli, for attachment to gut epithelium tissue, and bifidobacteria, to provide lumenal acidification. Most diets contain sufficient simple carbohydrates to support the growth of lactobacilli in the proximal areas of the digestive tract while complex carbohydrates, such as FOS, resist gastric digestion and can serve as bifidogenic factors in the lower gut. 
Acknowledgments. The authors would like to thank K. Stanich for excellent technical assistance.

\section{REFERENCES}

(1) Allais, J.J., G. Hoyos-Lopez, S. Kammoun, and J.C. Baratti. 1987. Isolation and characterization of thermophilic bacterial strains with inulinase activity. Appl. Environ. Microbiol. 53: 942-945.

(2) Allais, J.J., S. Kammoun, P. Blanc, C. Girard, and J.C. Baratti. 1986. Isolation and characterization of bacterial strains with inulinase activity. Appl. Environ. Microbiol. 52: 1086-1090.

(3) Bailey, J.S., L.C. Blankenship, and N.A. Cox. 1991. Effect of fructooligosaccharide on Salmonella colonization of the chicken intestine. Poult. Sci. 70: 2433-2438.

(4) Beeman, K. 1985. The effect of Lactobacillus spp. on convalescing calves. Agri-Practical 6: 8-9.

(5) Hidaka, H., and T. Eida. 1988. Role of fructooligosaccharides for the improvement of intestinal flora and suppression of production of putrid substances. Shokuhin-Kogyo (Food Engineering) 31 : 52-58.

(6) Hidaka, H., T. Eida, T. Takizawa, T. Tokunaga, and Y. Tashiro. 1986. Effects of fructooligosaccharides on intestinal flora and human health. Bifidobacteria Microflora 5 : 37-50.

(7) Jernigan, M.A., and R.D. Miles. 1985. Probiotics in poultry nutrition-a review. World's Poult. Sci. J. 41 : 99-107.

(8) McKellar, R.C., and H.W. Modler. 1989. Metabolism of fructooligosaccharides by Bifidobacterium spp. Appl. Microbiol. Biotechnol. 31 : 537-541.

(9) Modler, H.W. 1993. Compounds which enhance the growth of probiotic bacteria, p. 35-44. In Proc. Int. Roundtable on Animal Feed Biotechnology, Ottawa, Ont., February 4-6, 1992.

(10) Modler, H.W. 1993. Bifidogenic factors: sources, metabolism and application. Int. Dairy J. (in press).

(11) Modler, H.W., R.C. McKellar, and M. Yaguchi. 1990. Bifidobacteria and bifidogenic factors. Can. Inst. Food Sci. Technol. J. 23: 29-41.

(12) Muramatsu, K., S. Onodera, M. Kikuchi, and N. Shiomi. 1992. The production of betafructofuranosidase from Bifidobacterium spp. Biosci. Biotechnol. Biochem. 56: 1451-1454.

(13) Neu, H.C. 1992. The crisis in antibiotic resistance. Science 257: 1064-1073.

(14) Peterson, G.L. 1977. A simplification of the protein assay method of Lowry et al. which is more generally applicable. Anal. Biochem. 83: 346-356.

(15) Scardovi, V. 1986. Bifidobacterium, p. 1418-1434. In C.H. Sneath, N.S. Mair, M.E. Sharpe, and J.G. Holt (eds.), Bergey's manual of systematic bacteriology. Vol. 2. 9th ed., Williams and Wilkins Publishers, Baltimore.

(16) Schleifer, J.H. 1985. A review of the efficacy and mechanism of competitive exclusion for the control of salmonella in poultry. World's Poult. Sci. J. 41: 72-83.

(17) Snyder, H.E., and H.J. Phaff. 1960. Studies on a beta-fructosidase (inulinase) from Saccharomyces fragilis. A. Van Leeuwenhoek, J. Microbiol. Serol. 26: 433-453.

(18) Tannock, G.W. 1991. Modern methods and perspectives to assess the influence of nutritional factors, including live bacteria, on the gut microflora of man and farm animals. Proc. Int. Dairy Fed., Tokyo (Abstract).

(19) Tannock, G.W. 1992. Modern methods and perspectives to assess the influence of nutritional factors, including live bacteria, on the gut microflora of man and farm animals, p. 32-40. In Special Addresses at the International Dairy Federation Annual Sessions, Tokyo, Japan, 1991.

(20) Vanbelle, M., E. Teller, and M. Focurt. 1990. Probiotics in animal nutrition: a review. Arch. Anim. Nutr. (Berlin) 40: 543-567.

(21) Vandamme, E.J., and D.G. Derycke. 1983. Microbial inulinases: fermentation process, properties, and applications. Adv. Appl. Microbiol. 29: 139-176.

(22) Wren, W.B. 1989. Practical programs for cattle. Large Anim. Vet. 44: 18-21. 